\title{
Degradation of 2,4-dinitrophenol by Aspergillus niger AN 400 in batch reactors with immobilized biomass
}

\section{Renata Barros Silveira Brasil ${ }^{1}$, Bárbara Chaves Aguiar Barbosa $^{2}$, Kelly Rodrigues ${ }^{1}$ e Glória Marinho ${ }^{1}$}

${ }^{1}$ Instituto Federal de Educação, Ciência e Tecnologia do Ceará. Laboratório de Tecnologia Ambiental. Campus Fortaleza. Avenida 13 de Maio, 2081. Benfica. Fortaleza-CE, Brasil (CEP 60040-531).

${ }^{2}$ Instituto Federal de Educação, Ciência e Tecnologia do Maranhão. Campus Itapecuru Mirim. Rua Projetada, S/N. Centro. Itapecuru-MA (CEP 65485-000). Email: barbara.barbosa@ifma.edu.br.

Abstract. Aspergillus niger AN 400 was tested in the treatment of a synthetic water containing 2,4-dinitrophenol (2,4-DNP) by operating batch reactors with immobilized biomass. The treatment was carried out in two stages: 1) accomplished growth of fungal inoculum Aspergillus niger AN 400, and 2) the biomass was immobilized on a support at a concentration of $2 \times 10^{6} \mathrm{~mL}^{-1}$ of spores. The reaction times (RT) were 168, 48, 24 and, $8 \mathrm{~h}$. The variables analyzed were COD, $\mathrm{pH}$ and nitrogen fractions. Decay temporal (RT168 h) of 2,4-DNP and COD adjusted to the firstorder model. The higher removal efficiency 2,4 DNP was $96 \%$ and COD was $83 \%$. There was a decrease of sequencing batch reactor SBR efficiency when RT were $8 \mathrm{~h}$. The use of Aspergillus niger AN 400 may be an alternative treatment of wastewater containing nitrophenolic compounds.

Keywords: Nitrophenols; Fungi; Biodegradation; Batch reactors.

Resumo. Degradação de 2-4-dinitofenol por Aspergillus niger AN 400 em reatores em batelada com biomassa imobilizada. 0 Aspergillus niger AN 400 foi testado no tratamento de uma água sintética contendo 2,4 dinitrofenol (2,4 DNP) em reatores em batelada com biomassa imobilizada. 0 tratamento foi realizado em duas etapas: 1) realizou-se crescimento do inóculo fúngico de Aspergillus niger AN 400, e 2) a biomassa foi imobilizada em suporte com concentração de $2 \times 10^{6} \cdot \mathrm{mL}^{-1}$ de esporos. Os tempos de reação (TR) foram de 168, 48, 24 e 8 h. As variáveis analisadas foram frações de nitrogênio, $\mathrm{DQO}$ e $\mathrm{pH}$. 0 tempo reacional (TR $168 \mathrm{~h}$ ) de 2,4-DNP e DQO foram ajustados ao modelo de primeira ordem. A maior eficiência de remoção foi de 2,4 DNP e o DQO foi de $83 \%$. Houve uma diminuição da eficiência do reator em batelada com biomassa imobilizada quando o TR foi de 8 h. 0 uso de Aspergillus niger AN 400 pode ser um tratamento alternativo de águas residuais contendo compostos nitrofenólicos.
Received

March 10, 2021

Accept

April 25, 2021

Released

April 30, 2021

Open access

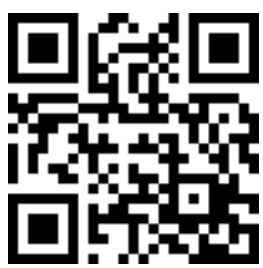

ORCID

(D) 0000-0002-1222-5923 Renata Barros Silveira Brasil

(D) 0000-0002-1151-9540 Bárbara Chaves Aguiar Barbosa

D) 0000-0003-4340-0269 Kelly Rodrigues

(D) 0000-0002-2515-5856 Glória Marinho

ISSN 2359-1412/RBGAS-2021-0025/2021/8/18/41/623

Rev. Bras. Gest. Amb. Sustent.

http://revista.ecogestaobrasil.net 
Palavras-chave: Nitrofenol; Fungos; Biodegradação; Reatores em batelada.

\section{Introduction}

Nitrophenols are widely used as synthetic compounds in the manufacture of pesticides, dyes, rubber chemicals, explosives, wood preservatives and industrial solvents intermediates (Gupta et al., 2006; Gemini et al., 2007; She et al., 2012) and, consequently, can be found in effluents, soil and underground environments. During the production of nitrobenzene, 2,4-DNP is generated and accumulated in waste water (Kulkarni, 2013). Like most nitrophenols, 2,4-DNP is highly toxic to living organisms. This compound is considered a "priority pollutant" and its concentration in natural waters has been restricted to $0.01 \mathrm{mg} \mathrm{L}^{-1}$ (Gemini, et al., 2007).

Many studies on treatment solutions to eliminate nitrophenols have been conducted. Electrochemical methods by using the electron as the main reagent, have high efficiency and are clean processes, but may require higher costs when compared to biodegradation processes (Nogueira, 2009). Microorganisms have the ability to interact chemically and physically with the substances causing structural alterations or complete degradation of the target molecule. Among the microbial communities, bacteria and fungi are the main degraders of this type of molecules.

Fungi are the main producers of oxidative enzymes for remediation of environments polluted by xenobiotics. These organisms are more effective, as being resistant organisms which can tolerate higher concentrations of pollutants than bacteria (Soares et al., 2011; Pinto et al., 2012). Different fungal species were successfully employed on degradation of phenolic compounds from wastewater Aspergillus flavus, Claddosporium sp, Penicillium sp. and Phoma sp. (Silva et al., 2013). Marinho et al. (2012) used the species Aspergillus niger AN 400 to remove the atrazina and methylparathion, reach in group to $60 \%$ and $94 \%$ of pesticides removal, respectively.

In this work, the ability of the filamentous fungus Aspergillus niger AN 400 to degrade 2,4-DNP present in a synthetic water, was tested by operating batch reactors with immobilized biomass.

The use of biological sequencing batch reactors (SBR) became extensive in the 80 due to the possibility of treatment of a variety of effluents. Currently, SBR are widely applied in the production of a variety of pharmaceutical and biological products, as well as in wastewater treatment and polymerization industry, and are generally considered more versatile than the equivalent continuous processes (Ming et al., 2013).The principle of operation in batch processes is the inclusion of all units of the process in a single tank, where all stages of treatment occur, such as aeration and sedimentation tank, and complete mixing is achieved by programming cycles at set periods (von Sperling, 1997).

\section{Materials and methods}

\section{inoculum \\ Cultivation, production and counting of the Aspergillus niger AN 400 \\ Spores of Aspergillus niger AN 400 were cultured in sterile Petri dishes (16 plates)} containing $15 \mathrm{~mL}$ of culture specific fungal growth medium Sabouraund, which was previously sterilized for $15 \mathrm{~min}$ at $121^{\circ} \mathrm{C}$ and pressure between 1 and $1.5 \mathrm{kgf.cm}^{-2}$. A Vishniac solution at a concentration of $1 \mathrm{~mL}^{-1} \mathrm{~L}^{-1}$ culture medium was also added.Vishniac solution is composed of $4.40 \mathrm{~g} \mathrm{~L}^{-1} \mathrm{ZnSO}_{4} .7 \mathrm{H}_{2} \mathrm{O}, 1.00 \mathrm{~g}^{-\mathrm{L}^{-1}} \mathrm{MnCl}_{2} .4 \mathrm{H}_{2} \mathrm{O}, 0.32 \mathrm{~g} . \mathrm{L}^{-1} \mathrm{CoCl}_{2} .6 \mathrm{H}_{2} \mathrm{O}$, 
0.22 g.L. ${ }^{-1}\left(\mathrm{NH}_{4}\right)_{6} \mathrm{Mo}_{7} \mathrm{O}_{24} \cdot 4 \mathrm{H}_{2} \mathrm{O}, 1.47$ g.L. $\mathrm{LaCl}_{2} \cdot 2 \mathrm{H}_{2} \mathrm{O}$, and 1.00 g.L $\mathrm{L}^{-1} \mathrm{FeSO}_{4} \cdot 7 \mathrm{H}_{2} \mathrm{O}$ (adapted from Sampaio, 2005).

Spores were inoculated on the plates and maintained on a microbiological incubator at a temperature of $28{ }^{\circ} \mathrm{C} \pm 2{ }^{\circ} \mathrm{C}$, for a period of seven days, period necessary to obtain the growth of the fungus on the total surface of the plates. Subsequently, the spores were removed with the use of normal saline containing Tween 80 solution, transferred and stored in a sterile flask and kept refrigerated at $0{ }^{\circ} \mathrm{C}$. For counting spores, a solution was prepared using $50 \mu \mathrm{L}$ of the suspension, previously stirred in a vortex, and $950 \mu \mathrm{L}$ of a Tween 80 solution, resulting in a dilution of 1:20. Then, $20 \mu \mathrm{L}$ of this prepared solution was transferred to a Neubauer chamber for counting the spores using light microscopy brand with a $40 \mathrm{x}$ magnification solution. The number of spores was calculated by the following Equation 1 (Sampaio, 2005):

Spores $/ \mathrm{mL}=$ spores counted $\times$ dilution $\times 2.5 \times 10^{5}$

Equation (1)

\section{Immobilization of biomass}

Polyurethane foam, cut in to cubes of 1 inch of edge (15 g) was used as the support medium for immobilization of the microorganisms. After the sterilization in autoclave under pressure of 1 to $1.5 \mathrm{kgf.cm}^{-2}$ at $121{ }^{\circ} \mathrm{C}$ for $15 \mathrm{~min}$, the cubic matrices were placed in three polyethylene nets inside the reactor. The reactor used was made of glass sealed with plastic cover and had a total volume of $5 \mathrm{~L}$, with a working volume of $4 \mathrm{~L}$ with a capacity of $5 \mathrm{~L}$, which was filled with $4 \mathrm{~L}$ of mineral medium, composed of 0.50 g. $\mathrm{L}^{-1}\left(\mathrm{NH}_{4}\right)_{2} \mathrm{SO}_{4}$, 0.25 g.L. $\mathrm{L}^{-2} \mathrm{NaNO}_{3}, 0.20$ g.L $\mathrm{L}^{-1} \mathrm{KH}_{2} \mathrm{PO}_{4}, 0.25$ g.L ${ }^{-1} \mathrm{MgSO}_{4}, 0.01$ g.L. ${ }^{-1} \mathrm{CaCl}_{2} .2 \mathrm{H}_{2} \mathrm{O}, 0.08$ g.L. ${ }^{-1}$ $\mathrm{CuSO}_{4} .7 \mathrm{H}_{2} \mathrm{O}, 0,05$ g.L. ${ }^{-1} \mathrm{H}_{2} \mathrm{MoO}_{4}, 0.05$ g.L.- ${ }^{-1} \mathrm{MnSO}_{4} .5 \mathrm{H}_{2} \mathrm{O}, 0.05$ g.L ${ }^{-1} \mathrm{Fe}_{2}\left(\mathrm{SO}_{4}\right)_{3}, 0.04$ g.L.- $\mathrm{ZnSO}_{4}$ (adapted from Rodrigues, 2006).

Immediately after the addition of the mineral medium in the reactor, glucose was added at a concentration of 5 g.L. ${ }^{-1}$, followed by inoculation with a spore suspension of 2 $\mathrm{x} 10^{6}$ spores $\mathrm{x} \mathrm{mL}{ }^{-1}$. The aeration of the reactor was supplied by mini compressors with a capacity of $50 \mathrm{~L}^{-\mathrm{h}^{-1}}$ at the power of $5 \mathrm{~W}$, and diffused into the medium by porous rocks. Immobilization lasted 15 days, changing the mineral medium every three days in order to promote better growth of fungi.

\section{Operation of sequencing batch reactor with immobilized biomass of Aspergillus niger AN 400}

The feed was prepared from a stock solution ( 5 mg.L-1 of 2,4-DNP), 1 mL.L-1 of the Vishniac solution, $2 \times 10^{6}$ spores $\mathrm{mL}^{-1}$ of Aspergillus niger AN 400, 0.5 g.L.-1 of glucose and tap water. The air was supplied by the mini compressors, as explained before. The reactor was operated at 4 retention times $(168,48,24$, and $8 \mathrm{~h})$. Each RT is operated in 4 cycles. At the beginning of each cycle the synthetic waste water was renewed. For the RT of $168 \mathrm{~h}, \mathrm{a}$ sample was taken every $24 \mathrm{~h}(0,12,24,48,72,96$, and $168 \mathrm{~h})$ in order to determine a decay kinetics of 2.4 DNP and COD.

During the reactor operation, the $\mathrm{pH}$, chemical oxygen demand (COD), concentration of 2,4-DNP, ammonia, nitrate and nitrite, were measured in duplicate and executed according to APHA (2005), except the concentrations of 2,4-DNP, whose determination was performed by high performance liquid chromatography (HPLC) accorging Fan et al. (2011). 


\section{Results and discussion}

Previous studies have demonstrated that the use of immobilized fungal biomass is more effective on the degradation or removal of target pollutants as compared to free or dispersed biomass (Papagianni and Mattey, 2004). Figures 1 and 2, show the values of 2.4 DNP and COD obtained in the synthetic wastewater sequencing batch reactors with immobilized in TR biomass of $168 \mathrm{~h}$.

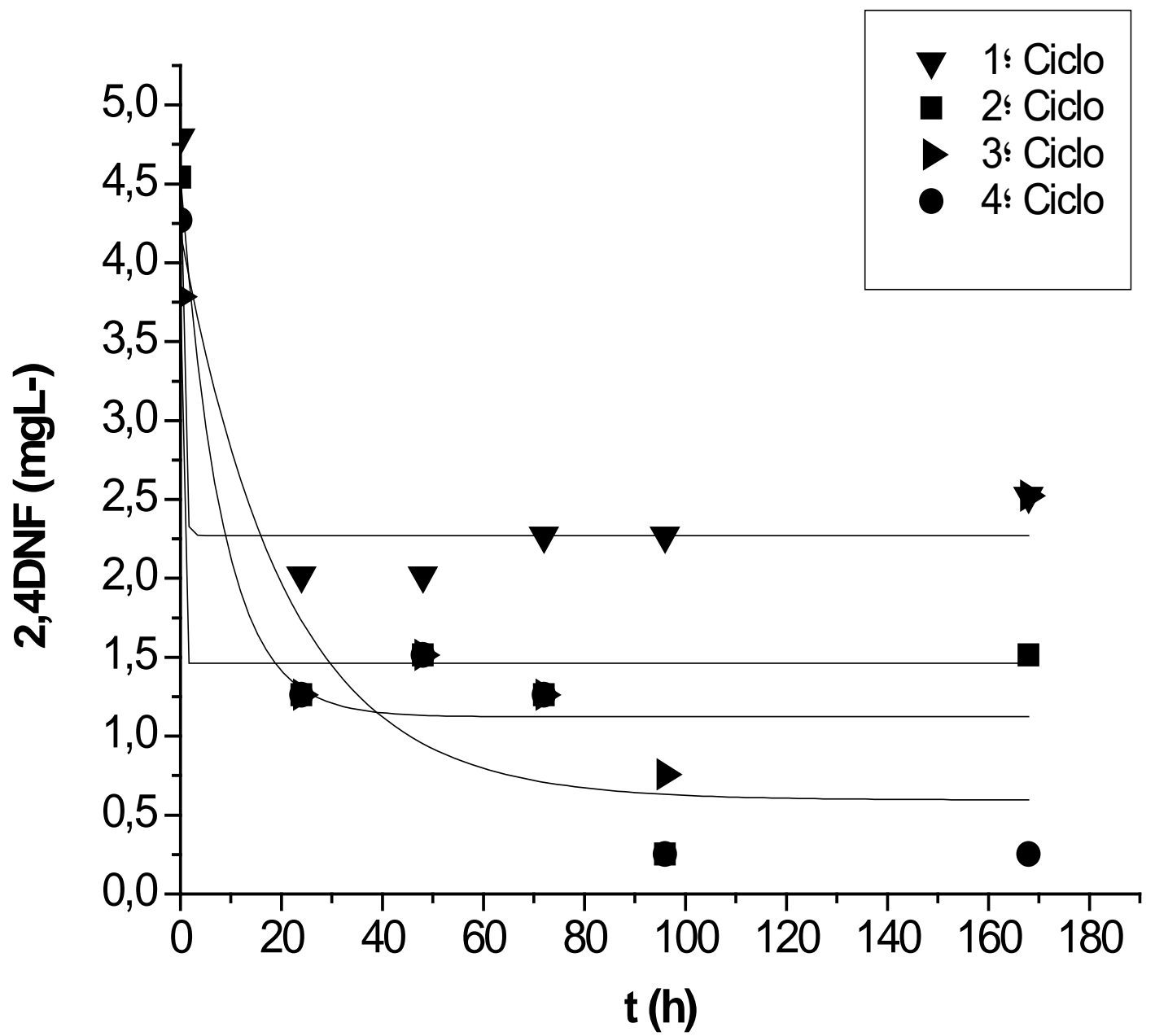

Figure 1. Values 2,4-DNP expressed in $\left(\mathrm{mg}^{\left.-\mathrm{L}^{-1}\right)}\right.$ obtained in the synthetic wastewater sequencing batch reactors with immobilized in TR biomass 0 to168 $\mathrm{h}$.

There was degradation of 2,4-DNP and COD in all cycles $(1,2,3$, and 4$)$, the better results in cycle 4 (94\% removal of 2,4-DNP and decay kinetics constant of $0.048 \mathrm{~h}^{-1}, 83 \%$ (Table 1). The decay of the two variables was adjusted to a first-order kinetics. Higher decay kinetics 2,4-DNP was presented in the first cycle, and this can be explained by an initial adsorption process, leading to a higher rate. However, there was in cycle 4 that has a higher efficiency, and can be justified by the increase of the cell retention time, from the biomass, resulting a 94\% removal of 2,4-DNP (Table 1). 
Table 1. Decay kinetics constant and percentages of removal of 2,4DNP and COD in cycles $1,2,3$, and 4 over time ( 0 to $168 \mathrm{~h}$ ).

\begin{tabular}{|c|c|c|c|c|c|c|}
\hline \multirow{2}{*}{ Cycles } & \multicolumn{3}{|c|}{$\mathbf{2 , 4 - D N P}$} & \multicolumn{3}{c|}{ COD } \\
\cline { 2 - 7 } & $\mathbf{k}\left(\mathbf{h}^{-\mathbf{1}}\right)$ & $\mathbf{R}^{\mathbf{2}}$ & Removal (\%) & $\mathbf{k}\left(\mathbf{h}^{-\mathbf{1}}\right)$ & $\mathbf{R}^{\mathbf{2}}$ & $\begin{array}{c}\text { Removal } \\
\mathbf{( \% )}\end{array}$ \\
\hline 1 & 2.192598 & 0.93572 & 47 & 0.0800 & 0.8033 & 54 \\
\hline 2 & 0.122858 & 0.83101 & 67 & 2.2524 & 0.8599 & 58 \\
\hline 3 & 13.75516 & 0.5411 & 33 & 2.0715 & 0.9020 & 64 \\
\hline 4 & 0.048073 & 0.83061 & 94 & 7.8015 & 0.8847 & 83 \\
\hline
\end{tabular}

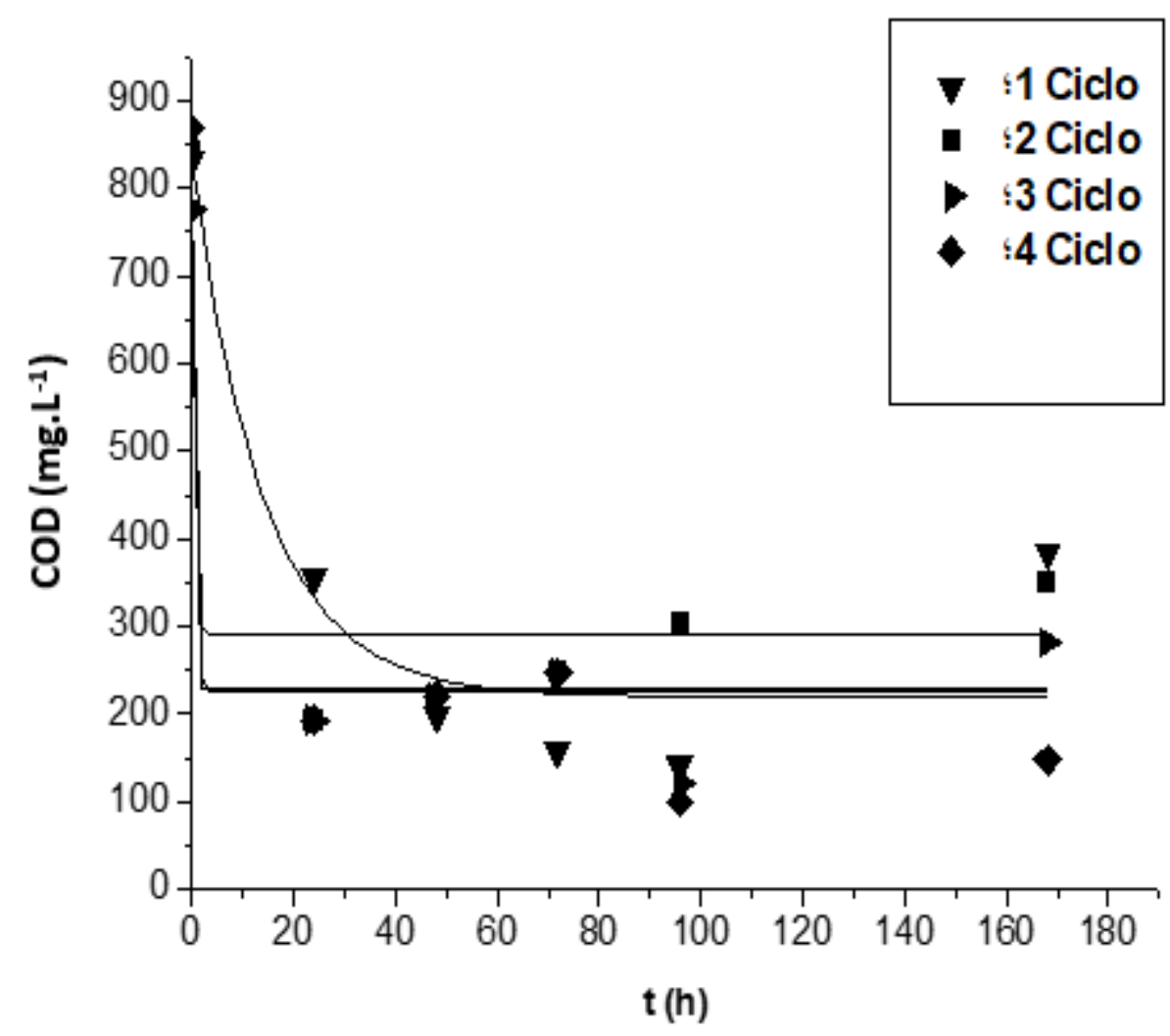

Figure 2. Values COD expressed in $\left(m g \cdot L^{-1}\right)$ obtained in the synthetic water sequencing batch reactors with immobilized in TR biomass of 0 to $168 \mathrm{~h}$.

The behavior of COD in cycles 1, 2, 3 and, 4, TR of $168 \mathrm{~h}$ showed a removal of organic matter COD of 54\%, 58\%, 64\%, and 83\%, respectively. For 2,4 DNP the removal of was $47 \%, 67 \%, 33 \%$, and $94 \%$ (Table 1), thus showing that the biomass was adapting the environment and improving the conditions for removal. The initial in stability about the COD and 2,4 DNP may be related to the presence of by-products formed in the middle, or even substances secreted by the fungus from its metabolism (Wanderley, 2007).

Gemini et al. (2007) stated that the process of biological removal of 2,4-DNP is complex. It has been reported that when nitro groups, electron-electron retreatants, are present as substituents on aromatic rings are not easy to suffer attack by oxygenases, which by contrast is often observed in aromatic xenobiotics $o$-nitrophenol and $p$-nitrophenol. Thus the initial reduction of aromatic systems is likely to be biological and not by oxidative attack. Rhodococcus opacus degraded $0.27 \mathrm{mM}$ 2,4-DNP more than $99.5 \%$ in $22 \mathrm{~h}$. 
In cycles 1 and 2 the immobilized batch showed that the highest removal of 2,4-DNP occurred in the first $24 \mathrm{~h}$, reaching respectively, $47.4 \%$ and $66.7 \%$. The $\mathrm{pH}$ value for the first cycle in $24 \mathrm{~h}$ was 2.9 and the value at cycle 2 was 6.1 . In cycles 3 and 4 , where the reaction times were only analyzed 96 and $168 \mathrm{~h}$ was removed from the 2,4-DNP, $33.4 \%$ and $94.1 \%$, respectively. As already mentioned, the use of immobilized biomass improves reactor performance, including the degradation of 2,4-DNP.

A decrease in $\mathrm{pH}$ was shown in the experiment, however in the interval between $72 \mathrm{~h}$ and $168 \mathrm{~h}$ was increased. The initial $\mathrm{pH}$ value of 6.7 through to 4.3 at the end of cycle 1 , showed good conditions for growth of Aspergillus niger AN 400, however fungi can tolerate wide range of $\mathrm{pH}$ between 2 and 9, the optimum $\mathrm{pH}$ being approximately 5.6 (Rodrigues, 2006). The decay observed in $\mathrm{pH}$ values can be explained by the probable formation of organic acids, oxalic acid and acetic acid by Aspergillus niger AN 400, as well as the production of ammonium ion $\left(\mathrm{NH}_{4}+\right.$, which releases $\mathrm{H}^{+}$formatting the acid medium (Kavitha and Palanivelu, 2005).

With regard to nitrogenous fractions, the ammonium ion $\left(\mathrm{NH}_{4}^{+}\right)$is considered the preferred source of nitrogen from fungi and bacteria (Griffin, 1994; Geisseler et al., 2010) so it should have been consumed by Aspergillus niger AN 400 for their growth and nutrition were not observed in cycle 1 . Was from cycle 2 , where in the fungus was already adapted to the immobilized means that the variables and ammonium nitrate began to decline indicating consumption, preferably the nitrate and then ammonia (Figure 3).

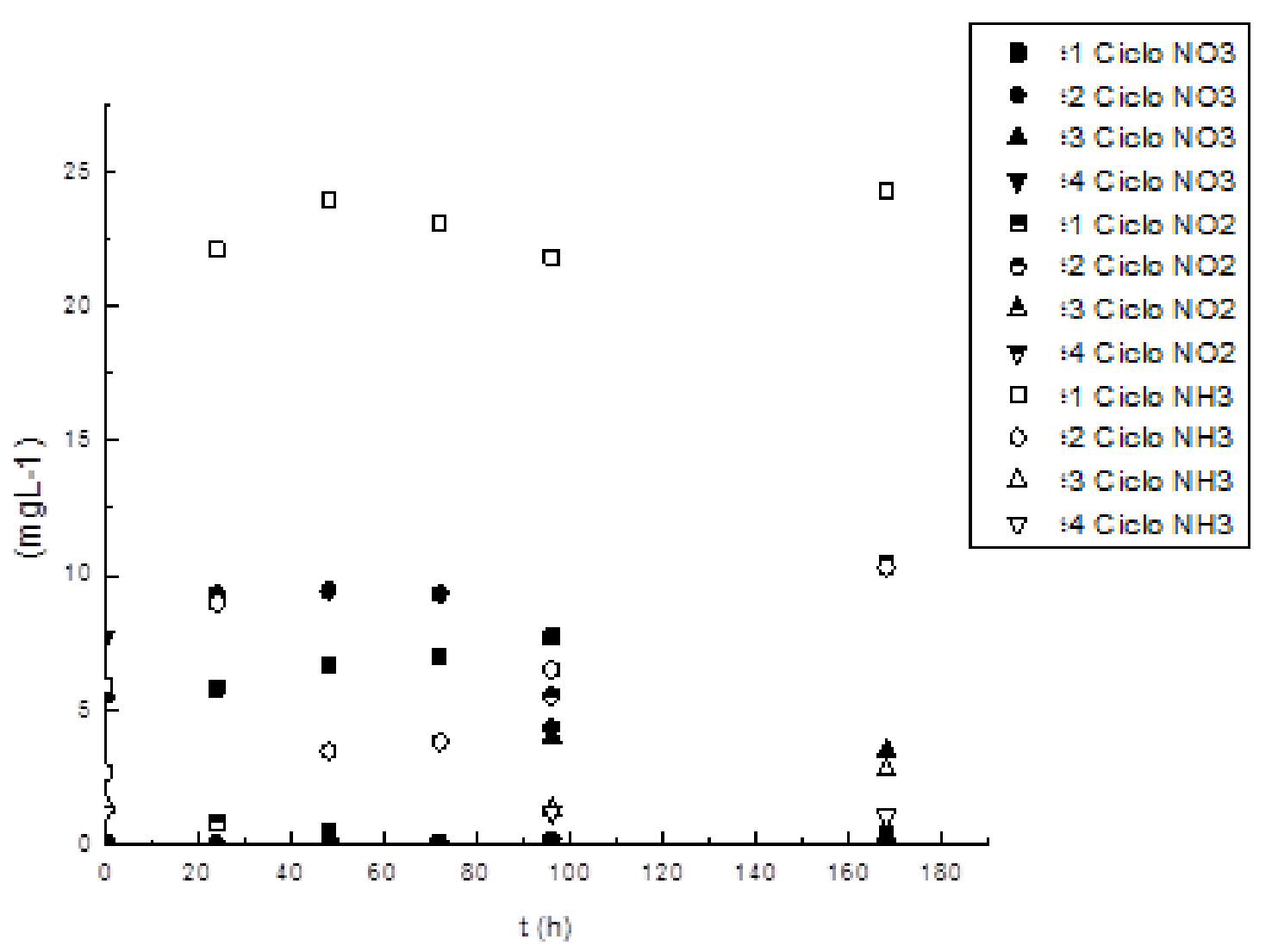

Figure 3. Values nitrite, nitrate and ammonia $\left(\mathrm{mg} \cdot \mathrm{L}^{-1}\right)$ obtained in the synthetic wastewater sequencing batch reactors with immobilized in RT biomass of 0 a $168 \mathrm{~h}$. 
Forms of inorganic nitrogen contained in wastewater, either ammonium ion or ammonia $\left(\mathrm{NH}_{3}\right)$ strongly depend on the $\mathrm{pH}$. For values less than or equal to $\mathrm{pH} 7$ ammonium ion is most prevalent. For pH values between 8 and 9 ammonia grows from $8 \%$ to $70 \%$ and above pH 11 ammoniais dominant (Sant'Anna Jr, 2010). According to the above, the dominant species in this study was ammonium ion, because the maximum value of $\mathrm{pH}$ was 7.6.

Regarding the parameters nitrate $\left(\mathrm{NO}_{3}{ }^{-}\right)$and ammonia in cycle 1 significant increase of concentrations. This suggests that sources of nitrogen were much higher than the consumption needs of the fungus, it is noteworthy that the nitrogen in the medium was coming from the 2,4-DNP, nutrients added to the medium contained in the solution of Vishniac and the detachment of biomass material support observed in this part of the research.

In the four cycles, the concentrations of nitrite released during the degradation of 2,4-DNP was low while the concentration of nitrate in the solution was high, showing that the nitrite oxidation occurred at this lower concentration remaining in the medium.

Inorganic nitrate is an excellent usable for many filamentous fungi source. Transportation to the intracellular environment is mediated by the nitrate permease and after assimilation, the sequential reduction of nitrate to nitrite and nitrite to ammonia catalyzed respectively by the enzymes nitrate and nitrite reductase (Griffin, 1994), as evidenced in this study occurs wherein the nitrite concentrations were small, probably due to the high concentrations of nitrate and ammonium in the medium.

Magri et al. (2013) also found the same pattern of detachment from the biofilm reactor in the nitrification process using oyster shells as support material. In the early days of the nitrification process, nutrients are required for cell synthesis, reactions were for the formation and stabilization of biomass in the system, and not for the oxidative processes. Also according to Magri et al. (2013), nitrate was formed from influent organic nitrogen is converted to ammonia and this enters the nitrification cycle. Increasing the concentration of ammonia nitrogen was derived from the cells that form the biofilm was detached. The detachment of biofilm favors transfer rates of oxygen to the biofilm autotrophic nitrification raisin grates by increasing the concentration of nitrates. In this research, can be observed variation quantities of nitrate and ammonia in batch immobilized.

$\mathrm{Li}$ and Kane (2008) explained the balance of nitrate and ammonia because the metabolism of fungi have storage of excess nitrogen in their vacuoles. Therefore, whenever there is the need to maintain the $\mathrm{pH}$ balance with in the cells, they release in to the medium ammonia and $\mathrm{H}^{+}$, which relates the concentration of nitrate in the medium with ammonia. Also according to $\mathrm{Li}$ and Kane (2008), there is release of stored nitrogen compounds within the mold in the form of amino acids into the medium and these directly converted to $\mathrm{NH}_{4}{ }^{+}$, and may justify the low values of removal of ammonia, similarly occurred in this part of the study.

Inhibition may also occur on the use of nitrate and nitrite intracellular ammonia is converted to nitrate within the cell (Haq et al., 2005), which may at times have succeeded in this study, particularly in cycle 1 , in which there was a lower consumption of these two variables.

For Nakano et al. (2004), the path of the photocatalytic degradation of 2,4-DNP is performed as follows: first is made $\mathrm{NO}_{2}$-(nitrite) from 2,4-DNP then $\mathrm{NO}_{3}$ - (nitrate or $\mathrm{N}$ oxidized) and $\mathrm{NH}_{4}{ }^{+}$(ammonia-N) are formed sequentially and there action rates for each component have been postulated too be rate law first order. According Satheeshkumar et al. (2019), assimilation of ammonia and nitrate by fungi occurs at different speeds, such as Aspergillus niger.

In general, analyzing the values of $\mathrm{pH}$, ammonia and nitrate, there has been a direct relationship between these parameters. At the end of each cycle we have the following 
correlations: in cycle 1 the $\mathrm{pH}$ is equal to 4.3 , there was production of both ammonium ion $(75.7 \%)$ and nitrate $(85.7 \%)$, revealing that the fungus does not use nitrogen as an energy source. In cycle 2 for $\mathrm{pH}$ equal to 7.4 have consumption of nitrate (36.4\%) and production of ammonium ion (73.8\%), similar to cycle 3 was obtained 2 cycle behavior, consumption of nitrate $(38.6 \%)$ and production of ammonium ion (50\%) in these cases, showed the preference of nitrate by Aspergillus niger AN 400. In cycle 4 when the $\mathrm{pH}$ is 7.2 been consumed nitrate $(99.9 \%)$ and ammonium ion (57\%), showing that the fungus was adapted to medium.

With further regard to $\mathrm{pH}$, Wang et al. (2010) investigated the effect of this parameter on the degradation of 2,4-DNP advanced oxidation processes for modifying the initial $\mathrm{pH}$ of 2.4, between 2.5 and 7.3 DNP found that removing 2.4, DNP decreased with the increase of $\mathrm{pH} 2.5$ to 7.3. The maximum degradation of 2,4-DNP was observed with in 70 min at $\mathrm{pH} 2.5$, which is the optimum $\mathrm{pH}$. This can be attributed to the degradation of 2,4-DNP organic acids, such as degradation proceeds, leading to a drop in the $\mathrm{pH}$ of the solution and thus accelerating the removal process. Thus, the $\mathrm{pH}$ is an important parameter in heterogeneous photo-Fenton reactions and biological processes. According to the $\mathrm{pH}$, may suggest the characteristics of the products formed from degradation.

The present study has not been properly quantified the likely metabolites of the degradation of 2,4-DNP, there may have been a likely mechanistic change with the formation of new, condensed or more recalcitrant products that eventually are also more nitrogen, although the reduction is possible of nitrate aminoor hydroxyl amino derivatives groups (Perchet et al., 2008). 2-amino-4-nitrophenol (2-ANP) is known as degradation product of 2,4-DNP (Hirooka et al., 2006; Karim and Gupta, 2006; Arora et al., 2014), a potent agent mutagenic and must also be removed from industrial effluents (Hirooka et al., 2006).

Kavitha and Palanivelu (2005), in his work on degradation of 2,4-DNP by Fenton and photo-Fenton processes monitored aliphatic acids of low molecular weight, such as oxalic acid and acetic acid. The oxalic and acetic acids have accumulated in the system reaching to $\mathrm{pH} 2-4$. This $\mathrm{pH}$ values in these arch cycle 1also varied between 2 and 4suggesting the presence of these acids in the medium despite treatment processes are distinct.

In order to verify if the efficiency of the RBS would be maintained or even to present a better removal response, it was decided to maintain the biomass and to vary the RT in 48, 24, and $8 \mathrm{~h}$. The decrease in TR for $48 \mathrm{~h}$ did not interfere with the removal efficiency of 2,4 DNP and COD (Tables 2 and 3). The change of the RT from 7 days to $48 \mathrm{~h}$ implies cost savings, with consequent improvement in the quality of the technology. However, when RT was reduced to 24 and $8 \mathrm{~h}$ there was an efficiency loss of approximately $40 \%$ to $2.4 \mathrm{DNP}$ and $35 \%$ to COD. The loss of efficiency should be associated with a decrease in the contact time between biomass and synthetic wastewater.

Table 2. Percent removal of 2.4 DNP from cycles 1, 2, 4, and 4 for RTs of 48, 24, and $8 \mathrm{~h}$.

\begin{tabular}{|c|c|c|c|c|}
\hline TR (h) & Cycle 1 & Cycle 2 & Cycle 3 & Cycle 4 \\
\hline 48 & 97 & 94 & 99 & 94 \\
\hline 24 & 47 & 50 & 47 & 59 \\
\hline 8 & 58 & 50 & 47 & 59 \\
\hline
\end{tabular}


Table 3. Percent COD removal from cycles 1, 2, 4, and 4 for RTs of 48, 24, and $8 \mathrm{~h}$.

\begin{tabular}{|c|c|c|c|c|}
\hline TR (h) & Cycle 1 & Cycle 2 & Cycle 3 & Cycle 4 \\
\hline 48 & 82 & 80 & 86 & 85 \\
\hline 24 & $*$ & $*$ & 76 & 79 \\
\hline 8 & 28 & 23 & 29 & 29 \\
\hline
\end{tabular}

Comparing the concentrations of all variables RT, it was found that the time of $48 \mathrm{~h}$ was that which resulted in the best performance for removing fungus 2,4-DNP. By comparing the percentages of removal of the 2,4-DNP of times reaction 8,24 , and $48 \mathrm{~h}$, it was found that the time of $48 \mathrm{~h}$ was that which resulted in the best performance for removing 2,4-DNP.

Marinho et al. (2012) studied the variation of hydraulic retention time in the posttreatment of effluent from the anaerobic filter used in the removal of synthetic textile dye dump by using biological reactor with fungi and found that during TRH of $6 \mathrm{~h}$, the value of removing dye was around 74\%, but the increase in TDH of $6 \mathrm{~h}$ to $8 \mathrm{~h}$ did not improve the removal of dye probably explained by the increased amount of compound excreted by the yeast due to increased contact time, resulting in decrease in removal organic matter and dye. The same was found in this research as best performance was observed in RT $48 \mathrm{~h}$ compared to $168 \mathrm{~h}$, as there was a greater response to removal of 2,4-DNP.

In this work the best RT for removal of the variables in question was $48 \mathrm{~h}$. The percentage removal of COD, 2,4-DNP, nitrate and ammonia reached was $86.2 \%, 99 \%, 99 \%$, and $87.3 \%$, values obtained between cycles 3 and 4 . These results indicate be use of fungi in reactors a promising technology for application in wastewater treatment and the search for the lowest RT will be reflected in lower cost to implement the treatment, should be emphasized the importance of further studies in this area. Although the present research concerned with the highest percentage removal of variables in water doped with 2,4-DNP, you must also list the final values with the legislation in order to verify the effective ness of treatment, and the need or no post-treatment to release the receiver body.

In relation to establishing the SEMACE Ordinance No. 154 of 2002 (Ceará, 2002) to the release of effluents in reactors with immobilized biomass, only RT $8 \mathrm{~h}$ does not meet the maximum value of 200 g.L. $\mathrm{L}^{-1}$ of COD, the effluent from this reactor showed a concentration end of $514 \mathrm{mg} \mathrm{L}^{-1}$, whereas in reaction time $168 \mathrm{~h}, 48 \mathrm{~h}$, and $24 \mathrm{~h}$, reached $148 \mathrm{mg} . \mathrm{L}^{-1}, 113 \mathrm{mg} . \mathrm{L}^{-1}$ and $165 \mathrm{mg} . \mathrm{L}^{-1}$, respectively, given the legislation.

In this same reactor, the TR $168 \mathrm{~h}$ showed the highest concentrations of nitrate and ammonia of all research. The concentrations of ammonia reached the end of treatment were $24.3 \mathrm{mg} \mathrm{L}^{-1}$ for $168 \mathrm{~h}, 0.41 \mathrm{mg} . \mathrm{L}^{-1}$ for $48 \mathrm{~h}, 0.58 \mathrm{mg} \mathrm{L}{ }^{-1}$ for $24 \mathrm{~h}$ and $0.68 \mathrm{mg} . \mathrm{L}^{-1}$ for $8 \mathrm{~h}$. These values, except for $168 \mathrm{~h}$, are in accordance with the provisions of Resolution CONAMA No. 430/2011 (Brasil, 2011) which defines the maximum value of $20 \mathrm{mg} . \mathrm{L}^{-1}$ for effluent discharge into receiving water.

\section{Conclusion}

This research proved efficient in the removal of 2,4-dinitrophenol (2,4-DNP) by sequencing batch reactor, obtaining a minimum value of $0.3 \mathrm{mg} \mathrm{L}^{-1}$. The best time to remove the degradation of 2,4-DNP with immobilized in polyurethane cubes fungal biomass was $48 \mathrm{~h}$. The percentage removal of COD, 2,4-DNP, nitrate and ammonia were achieved at this time $86.2 \%, 99 \%, 99 \%$, and $87.3 \%$. 


\section{Conflicts of interest}

The authors declare that have no conflicts of interest.

\section{References}

APHA - American Public Health Association. Standard methods for the examination of water and wastewater. 21. ed. Washington D.C: American Public Health Association, 2005.

Arora, S.; Mukherji, I.; Kumar, A.; Tanwar, R. K. Pesticide residue analysis of soil, water, and grain of IPM basmati rice. Environmental Monitoring Assessment, v. 186, p. 87658772, 2014. https://doi.org/10.1007/s10661-014-4042-9

Brasil. Resolução CONAMA no 430, de 17 de março de 2011. Dispõe sobre as condições e padrões de lançamento de efluentes, complementa e altera a Resolução no 357, de 17 de março de 2005, do Conselho Nacional do Meio Ambiente-CONAMA. Available from: $<$ http://www2.mma.gov.br/port/conama/legiabre.cfm?codlegi=646>. Accessed on: Feb. 03, 2020.

Ceará. Portaria no 154, de 22 de julho de 2002. Dispõe sobre padrões e condições para lançamento de efluentes líquidos gerados por fontes poluidoras, da. Superintendência Estadual do Meio Ambiente do Ceará - SEMACE. Available from: $<$ http://antigo.semace.ce.gov.br/integracao/biblioteca/legislacao/conteudo_legislacao.as p?cd=95>. Accessed on: Feb. 03, 2020.

EPA - Environmental Protection Agency. The benefits and costs of the clean air act, 1990 to 2010 - First Prospective Study. Washington: EPA, 1999. Available from: <https://www.epa.gov/sites/production/files/2015-07/documents/fullrept.pdf>.

Accessed on: Feb. 03, 2020.

Fan, C.; Tsui, L.; Liao, M.-C. Parathion degradation and its intermediate formation by Fenton process in neutral environment. Chemosphere, v. 82, p. 229-236, 2011. https://doi.org/10.1016/j.chemosphere.2010.10.016

Geisseler, D.; Horwath, W. R.; Joergensen, R. G.; Ludwig, B. Pathways of nitrogen utilization by soil microorganisms: A review. Soil Biology \& Biochemistry, v. 42, p. 2058-2067, 2010. https://doi.org/10.1016/j.soilbio.2010.08.021

Gemini, V. L.; Gallego, A.; Tripodi, V.; Corach, D.; Planes, E. I.; Korol, S. E. Microbial degradation and detoxification of 2,4-dinitrophenol in aerobic and anoxic processes. Inter Biodeterioration e Biodegradation, v. 60, p. 226-230, 2007. https://doi.org/10.1016/ j.ibiod.2007.03.006

Griffin, D. H. Fungal physiology. 2. ed. New York: Wiley-Liss, 1994.

Gupta, S. K.; Karim, K. Effect of skock and mixed nitrophenolic loadings on the performance of UASB reactors. Water Research, v. 40, p. 935-942, 2006. https://doi.org/10.1016/j.watres.2005.12.030

Haq, I. U.; Ali, S.; Qadeer, M. A.; Iqbal, J. Optimization of nitrogen for enhanced citric acid productivity by a 2-deoxy D-glucose resistant culture of Aspergillus niger NGd-280. Bioresource Technology, v. 96, no. 5, p. 645-648, 2005. https://doi.org/10.1016/ j.biortech.2004.06.010 
Hirooka, T.; Nagase, H.; Hirata, K.; Miyamoto, K. Degradation of 2,4-dinitrophenol by mixed culture of photoautotrophic microorganisms. Biochemical Engineering Journal, v. 29, p. 157-162, 2006. https://doi.org/10.1016/j.bej.2005.03.018

Karim, K.; Gupta, S. K. Effect of shock and mixed nitrophenolic loadings on the performance of UASB reactors. Water Research, v. 40, p. 935-942, 2006. https://doi.org/10.1016/j.watres.2005.12.030

Kavitha, V.; Palanivelu, K. Degradation of nitrophenols by Fenton and photo-Fenton processes. Journal of Photochemistry and Photobiology, v. 170, p. 83-95, 2005. https://doi.org/10.1016/j.jphotochem.2004.08.003

Kulkarni, P. Nitrophenol removal by simultaneous nitrification denitrification (SND) using T. pantotropha in sequencing batch reators (RSB). Bioresource Technology, v. 128, p. 273-280, 2013. https://doi.org/10.1016/j.biortech.2012.10.054

Li, S. C.; Kane, P. M. The yeast lysosome-like vacuole: Endpoint and crossroads of vacuoles. Biochimica et Biophysica Acta (BBA) - Molecular Cell Research, v. 1793, p. 650-663, 2009. https://doi.org/10.1016/j.bbamcr.2008.08.003

Magri, M. A. Otimização do processo de nitrificação com o uso de conchas de ostras como material suporte em reatores aeróbios com biomassa fixa. Engenharia Sanitária Ambiental, $\quad$ v. 18, p. 123-130, 2013. https://doi.org/10.1590/S141341522013000200004

Marinho, G.; Rodrigues, K. Fungos e águas residuárias industriais: nova tecnologia. 1. ed. Recife: Imprima, 2012.

Ming, D.; Glasser, D.; Hildebrandt, D. Application of attainable region theory to batch reactors. Chemical Engineering Science, v. 99, p. 203-214, 2013. https://doi.org/ 10.1016/j.ces.2013.06.001

Nakano, K.; Obuchi, E.; Takagi, S.; Yamamoto, A. R. Photocatalytic treatment of water containing dinitrophenol and city water over $\mathrm{TiO}_{2} / \mathrm{SiO}_{2}$. Separation and Purification Technology, v. 34, p. 67-72, 2004. https://doi.org/10.1016/S1383-5866(03)00176-X

Nogueira, M. I. C. Tratamentos adsortivos e de oxidação avançada de fenol, 2nitrofenol e 4-nitrofenol em solução aquosa. Fortaleza: Universidade Federal do Ceará, 2009. (Tese de doutorado).

Papagianni, M.; Mattey, M. Physiological aspects of free and immobilized Aspergillus niger cultures producing citric acid under various glucose concentrations. Process Biochemistry, v. 39, p. 1963-1970, 2004. https://doi.org/10.1016/j.procbio.2003.09.027

Perchet, G.; Sangely, M.; Goñi, M.; Merlina, G.; Revel, J.-C.; Pinelli, E. Microbial population changes during bioremediaation of nitroaromatic and nitramine-contamined lagoon. International Biodeterioration \& Biodegradation, v. 61, p. 304-312, 2008. https://doi.org/10.1016/j.ibiod.2007.10.003

Pinto, A. P.; Serrano, C.; Pires, T.; Mestrinho, E.; Dias, L.; Teixeira, D. M.; Caldeira, A. T. Degradation of terbuthylazine, difenoconazole and pendimethalin pesticides by selected fungi cultures. Science of the Total Environment, v. 435/436, p. 402-410, 2012. https://doi.org/10.1016/j.scitotenv.2012.07.027

Rodrigues, K. A. Uso de reatores biológicos com fungos para remoção de fenol de água residuária sintética. São Carlos: Universidade de São Paulo, 2006. (Tese de doutorado). 
Sampaio, G. M. M. S. Remoção de metil paration e atrazina em reatores de bancada com fungos. São Carlos: Universidade de São Paulo, 2005. (Tese de doutorado).

Satheeshkumar, S.; Sivagurunathan, P.; Muthulakshmi, K.; Uma, C. Utilization of fruit waste for the production of citric acid by using Aspergillus niger. Journal of Drug Delivery and Therapeutics, v. 9, n. 4-A, p. 9-14, 2019.

Sant'Anna Jr., G. L. Tratamento biológico de efluentes: fundamentos e aplicações. Rio de Janeiro: Interciência, 2010.

Sharma, N.; Gupta, V. C. Comparative biodegradation analysis of phenol from paper e pulp industrial effluent by free and immobilized cells of Aspergillus niger. International Conference on Environmental Science and Technology, v. 30, p. 68-72, 2012.

She, Z.; Xie, T.; Zhu, Y.; Li, L.; Tang, G.; Huang, J. Study on the aerobic biodegradability and degradation kinectics of 3-N, 2,4-DNP and 2,6-DNP. Journal of Hazardous Materials, v. 241/242, p. 478-485, 2012. https://doi.org/10.1016/j.jhazmat.2012.10.008

Silva, L. V. C.; Andrade, M. V.; Rodrigues, K.; Marinho, G. Tratamento sintético de laticínio em reatores em batelada inoculados com Aspergillus niger AN 400. Engenharia Sanitária Ambiental, v. $18, \quad$ n. $4, \quad$ p. 371-380, 2013. https://doi.org/10.1590/S141341522013000400009

Von Sperling, M. Princípios do tratamento biológico de águas residuárias: lodos ativados. Belo Horizonte: Editora SEGRAC; Universidade Federal de Minas Gerais, 1997. v. 4.

Wanderley, C. R. Aspergillus niger AN 400 como inóculo de reatores em batelada para remoção do corante vermelho de congo em meio aquoso sintético. Fortaleza: Universidade Federal do Ceará, 2007. (Dissertação de mestrado).

Wang, H.-L.; Liang, W.-Z.; Zhang, Q.; Jiang, W.-F. Solar-light-assisted Fenton oxidation of 2,4-dinitrophenol (DNP) using $\mathrm{Al}_{2} \mathrm{O}_{3}$ - supported Fe(III)-5-sulfosalicylic acid (SSAL) complex as catalyst. Chemical Engineering Journal, v. 164, p. 115-120, 2010. https://doi.org/10.1016/j.cej.2010.08.038

License information: This is an open-access article distributed under the terms of the Creative Commons Attribution License, which permits unrestricted use, distribution, and reproduction in any medium, provided the original work is properly cited. 